\title{
Androgen receptors in the rat epididymis and their hormonal control
}

\author{
A. Pujol and F. Bayard \\ Laboratoire d'Endocrinologie Expérimentale, Université Paul Sabatier (C.H.U.Rangueil), \\ 31054 Toulouse, France
}

\begin{abstract}
Summary. The concentrations of cytoplasmic receptor sites for androgens in the caput, corpus and cauda epididymidis, and the effect of ligation of the efferent ducts and testosterone treatment after bilateral castration on the concentration of receptors in the caput have been measured. Androgen receptors in the ventral prostate have been measured in the same animals for comparison. The caput has the highest concentration of receptor sites, the corpus the lowest. The ligation of the efferent ducts has no effect on this concentration which is dependent on testicular androgens. The present data do not yet allow explanation of the differential response of the different regions of the epididymis and of the other accessory glands to the administration of androgens.
\end{abstract}

\section{Introduction}

A differential requirement of androgens by the epididymis and other accessory glands for the maintenance of their weight and secretory activity as well as differences in the thresholds of androgens required for the maintenance of the different regions of the epididymis have been reported (Gupta, Rajalakshmi \& Prasad, 1974; Prasad, Rajalakshmi, Gupta \& Karkun, 1973). Investigation into the general mechanism of action of steroid hormones has demonstrated that an initial event involves the interaction of the steroid with a cytoplasmic protein receptor in target cells; this is followed by a translocation of the complex into the nucleus where it binds to the chromatin allowing the biological expression (Baulieu et al., 1975). Such cytoplasmic protein receptors for androgens have been described in the epididymis (Blaquier, 1971; Hansson, Ritzen, French \& Nayfeh, 1975). The present investigation was undertaken in order to approach the mechanism of the differential requirement of androgens which could result from a variable concentration of these structures in the different regions of the epididymis and in the other accessory glands.

\section{Materials and Methods}

\section{Steroids}

$\left[1,2,6,7(\mathrm{~N})^{3} \mathrm{H}\right]$ Testosterone, (sp. act. $91 \mathrm{Ci} / \mathrm{mmol}$ ) was obtained from the Radiochemical Centre, Amersham, England, and tritiated methyltrienolone (17 $\beta$-hydroxy, $17 \alpha$-methyl-estra4,9,11-trien-3-one: $\left[{ }^{3} \mathrm{H}\right] \mathrm{R} 1881$, sp. act. $\left.58 \cdot 2 \mathrm{Ci} / \mathrm{mmol}\right)$ was a generous gift from $\mathrm{Dr} \mathrm{J}$. P. Raynaud (Bonne \& Raynaud, 1975), Roussel UCLAF Laboratories. The steroids were stored in benzene-ethanol $(9: 1, \mathrm{v} / \mathrm{v})$ at $4{ }^{\circ} \mathrm{C}$ and checked regularly for purity by thin-layer chromatography. Radioinert testosterone was obtained from Sigma Chemical Company (St Louis, Missouri, U.S.A.) and radioinert R 1881 was a gift from Roussel UCLAF Laboratories. 
Experiment 1: measurement of the epididymal cytoplasmic receptors in the three segments of the epididymis and effect of ligation of the efferent ducts

Adult Wistar rats (2-3 months old) obtained from Evic Ceba (Blanquefort 33290, France) were maintained under controlled conditions of temperature and light and fed a standard rat chow. Ligation of an efferent duct, right or left alternately, was performed by the scrotal route under light ether anaesthesia. Care was taken to preserve the testicular and epididymal vasculature. After 6 days the rats were bilaterally castrated and $24 \mathrm{~h}$ later (between 07:30 and $08: 30 \mathrm{~h}$ ) the epididymides were removed, trimmed of fat, cooled immediately at $4^{\circ} \mathrm{C}$ and divided into three segments, caput, corpus and cauda, as previously described (Pujol, Bayard, Louvet \& Boulard, 1976). These three parts were separately minced with a razor blade, then homogenized in a glass-glass homogenizer with 10 volumes $(\mathrm{ml} / \mathrm{g}$ ) of an ice-cooled $20 \mathrm{~mm}$-Tris- $\mathrm{HCl}$ buffer, $\mathrm{pH}$ 7.4 , containing $1.5 \mathrm{~mm}$-EDTA, $1 \mathrm{mM}$-dithioerythritol and $10 \%$ glycerol (Tris buffer). Aliquots of the homogenate were kept for determination of the deoxyribonucleic acid (DNA) content (Burton, 1956). The homogenate was centrifuged at $105000 \mathrm{~g}$ for $60 \mathrm{~min}$ and aliquots of the supernatant (cytosol) were withdrawn for protein assay (Lowry, Rosebrough, Farr \& Randall, 1951). Aliquots of $0.1 \mathrm{ml}$ were incubated for at least $4 \mathrm{~h}$ at $0^{\circ} \mathrm{C}$ with various amounts $(0 \cdot 10-10$ $\left.\times 10^{-9} \mathrm{M}\right)$ of $\left[{ }^{3} \mathrm{H}\right]$ testosterone or $\left[{ }^{3} \mathrm{H}\right] \mathrm{R} 1881$. Receptor bound and unbound steroids were separated using protamine sulphate precipitation as described by Blondeau, Corpechot, Le Goascogne, Baulieu \& Robel (1975). The bound radioactivity was counted in a scintillation spectrometer, a correction being made for the counting efficiency by external standardization. The numbers of cytoplasmic receptor sites were expressed in fmol/mg DNA in the homogenate, or in $\mathrm{fmol} / \mathrm{mg}$ cytosol proteins.

Experiment II: effect of testosterone administration to castrated rats on the cytoplasmic receptors of the caput epididymidis and ventral prostate

Bilateral castration was performed in 20 rats 20 days before killing. Groups of 5 rats were treated with 0,1 or 2 Silastic (Dow Corning) capsules filled with testosterone, as described by Berndtson, Desjardins \& Ewing (1974). The capsules, i.d. $1.98 \mathrm{~mm}$, o.d. $3.18 \mathrm{~mm}$, length 2 $\mathrm{cm}$, were inserted subcutaneously on the back of the animals. Sham-operated rats served as controls and received no testosterone treatment. The capsules were removed 19 days after castration and the control rats were castrated. The following day the caput epididymidis and the ventral prostate were collected, quickly weighed and the androgen receptor concentration measured as described in Exp. 1.

\section{Statistical analysis}

Statistical comparison was made with Student's $t$ test for unpaired data.

\section{Results}

As shown in Text-fig. 1, R 1881 was bound to the epididymal cytosol of rats bearing a ligation of the efferent ducts for 7 days with a higher affinity than was testosterone, but with the same number of binding sites. Binding parameters calculated from the curves gave an equilibrium dissociation constant of $0.95 \times 10^{-9} \mathrm{M}$ for $\mathrm{R} 1881$ and $5.6 \times 10^{-9} \mathrm{M}$ for testosterone.

We repeatedly observed that a concentration of $5 \times 10^{-9} \mathrm{M}\left[{ }^{3} \mathrm{H}\right] \mathrm{R} 1881$ was a saturating concentration of the androgen receptor binding sites when the protein content per tube of assay was less than $5 \mathrm{mg} / \mathrm{ml}$. A similar observation was made in prostatic tissue. All subsequent measurements have been made at this saturating amount of labelled steroid and in these 
conditions of protein concentration. The non-specific low-affinity binding, measured in the presence of a 100 -fold excess of non-radioactive hormone, was subtracted from the 'total' binding measured in the presence of only the radioactive hormone. This non-specific binding constantly represented less than $35 \%$ (less than $20 \%$ in normal and testosterone-treated rats) of the total binding. No binding of $\mathrm{R} 1881$ could be demonstrated in the rete testis fluid. Finally, no metabolism of $R 1881$ could be observed after $24 \mathrm{~h}$ of incubation.

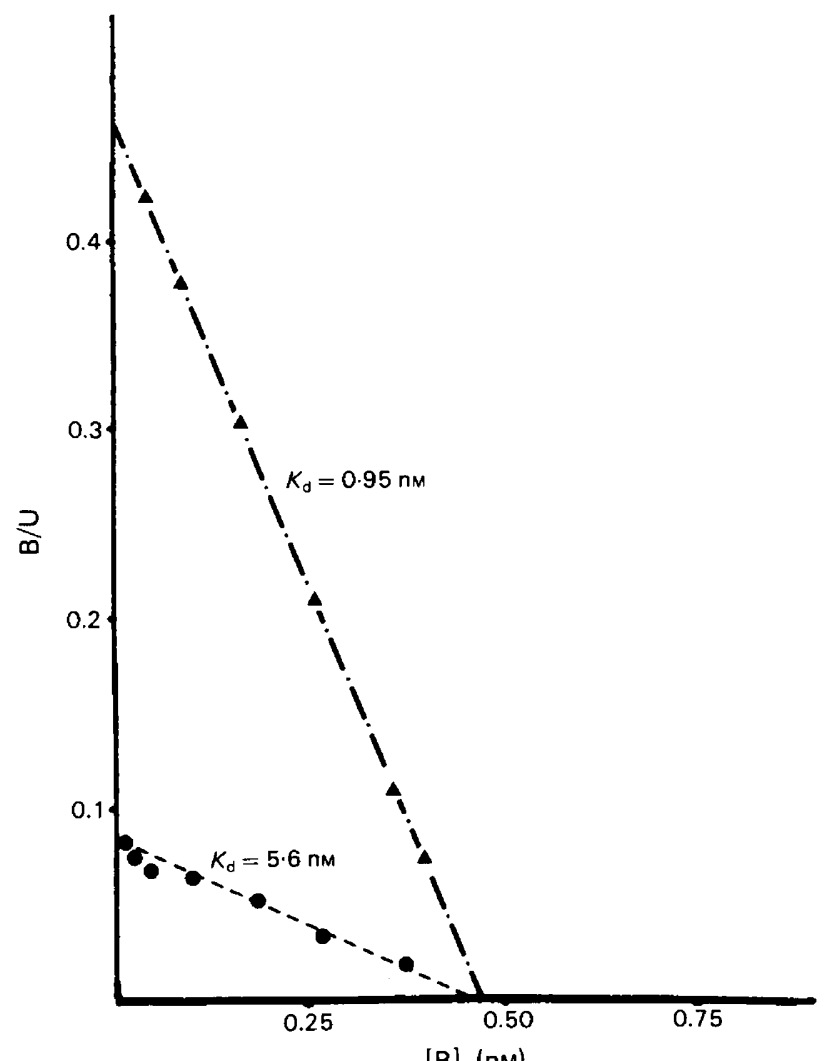

Text-fig. 1. Scatchard analysis (Scatchard, 1953) of testosterone ( () ) and $R 1881(\Delta)$ binding in epididymal cytosol of rats with ligation of the efferent ducts for 7 days.

\section{Experiment I}

The androgen receptor concentrations in the different segments of the epididymis are presented in Table 1. Ligation of the efferent ducts for 7 days did not affect the androgen receptor concentration of the cytosol of the caput epididymidis.

\section{Experiment $I I$}

As shown in Table 2, castration for 20 days resulted in a decrease of the androgen receptor content of the caput epididymidis as well as of the ventral prostate. One testosterone capsule restored the androgen receptor content (per $\mathrm{mg}$ protein) of the ventral prostate as well as the cytosol protein and DNA content (data not shown). Two capsules were necessary to obtain the same results in the caput epididymidis. At the dose of 2 capsules, all parameters were actually 
Table 1. Androgen receptor content in the three segments of the epididymis and effect of ligation of the efferent ducts

\begin{tabular}{lll}
\hline & \multicolumn{2}{c}{ Androgen 'receptor' } \\
\cline { 2 - 3 } & fmol/mg cytosol proteins & fmol/mg DNA \\
\hline Caput & & \\
$\quad$ Intact side & $30.0 \pm 5.5$ & $525.0 \pm 43.0$ \\
$\quad$ Operated side* & $30.7 \pm 6.0$ & $562.9 \pm 107.8$ \\
Corpus & $13.4 \pm 1.6$ & $243.0 \pm 34.0$ \\
Cauda & $13.9 \pm 4.7$ & $382.0 \pm 110.0$ \\
\hline
\end{tabular}

Values are mean \pm s.d. for 5 rats/group.

* Ligation of the efferent ducts for 6 days before castration.

higher than normal for the ventral prostate. When 4 capsules were introduced, no further amplification of weight, cytosol protein or DNA content was noted in either organ. Under these conditions the androgen receptor concentration decreased in both tissues. As shown in Text-fig. 2 , a statistically significant linear relationship between the androgen receptor concentrations in the caput epididymidis and ventral prostate of the castrated and treated animals was observed $(n$ $=20, r=0.72, P<0.005)$.

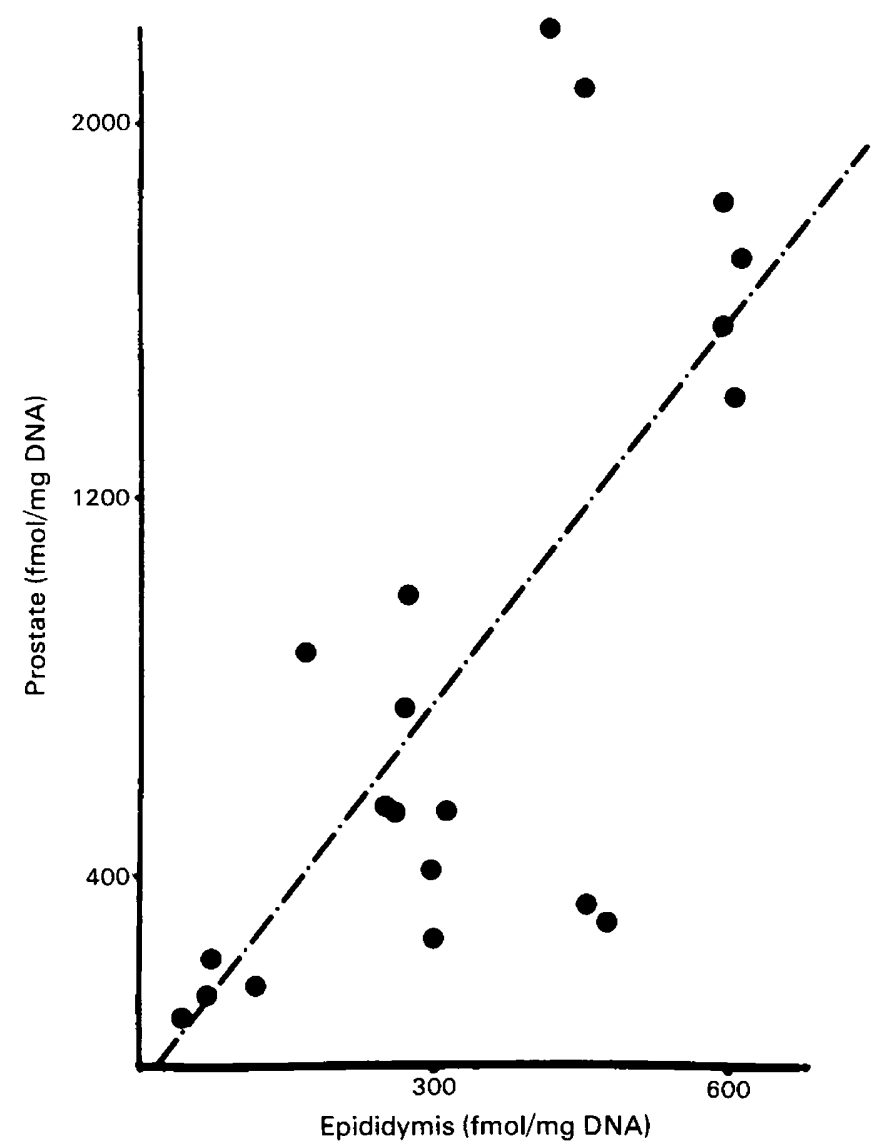

Text-fig. 2. Relationship between the androgen receptor concentration in the caput epididymidis and ventral prostate of the same rat. The regression equation is $y=31.9+2.67 x, r=0.72$. 
Table 2. Effect of castration and testosterone treatment on the mean \pm s.d. $(n=5)$ weight and androgen receptor content of the caput epididymidis and of the ventral prostate of rats

\begin{tabular}{|c|c|c|c|c|c|c|}
\hline & \multicolumn{3}{|c|}{ Epididymis } & \multicolumn{3}{|c|}{ Prostate } \\
\hline & \multirow[b]{2}{*}{$\begin{array}{l}\text { Weight } \\
\text { (mg) }\end{array}$} & \multicolumn{2}{|c|}{ Androgen 'receptor' } & \multirow[b]{2}{*}{$\begin{array}{l}\text { Weight } \\
\text { (mg) }\end{array}$} & \multicolumn{2}{|c|}{ Androgen 'receptor' } \\
\hline & & $\begin{array}{l}\mathrm{fmol} / \mathrm{mg} \\
\text { protein }\end{array}$ & $\begin{array}{c}\mathrm{fmol} / \mathrm{mg} \\
\text { DNA }\end{array}$ & & $\begin{array}{l}\mathrm{fmol} / \mathrm{mg} \\
\text { protein }\end{array}$ & $\begin{array}{c}\mathrm{fmol} / \mathrm{mg} \\
\text { DNA }\end{array}$ \\
\hline Sham-operated & $\begin{array}{r}254.9 \\
+15.0\end{array}$ & $\begin{array}{r}37.8 \\
+\quad 7.1\end{array}$ & $\begin{array}{r}626.9 \\
+48.4\end{array}$ & $\begin{array}{r}515.1 \\
+50.4\end{array}$ & $\begin{array}{r}61.2 \\
+4.0\end{array}$ & $\begin{array}{r}1406.5 \\
+288.6\end{array}$ \\
\hline Castrated & $\begin{array}{r}125 \cdot 7^{*} \\
\pm 17.4\end{array}$ & $\begin{array}{c}12.4^{*} \\
\pm 4.7\end{array}$ & $\begin{array}{r}74.9^{*} \\
\pm 30.9\end{array}$ & $\begin{array}{l}176.7^{*} \\
\pm 39.0\end{array}$ & $\begin{array}{c}26.0^{*} \\
\pm 5.7\end{array}$ & $\begin{array}{c}186.0^{*} \\
\pm 60.7\end{array}$ \\
\hline Castrated & $167 \cdot 7^{*}$ & $20 \cdot 0^{*}$ & $256 \cdot 5^{*}$ & $425 \cdot 9^{* *}$ & 47.9 & $802 \cdot 8^{* *}$ \\
\hline $\begin{array}{l}+1 \text { capsule } \\
\text { Castrated }\end{array}$ & $\pm 24 \cdot 0$ & $\pm 7 \cdot 6$ & \pm 48.9 & $\pm 86 \cdot 6$ & $\pm 26 \cdot 2$ & \pm 291.8 \\
\hline Castrated & $213 \cdot 3^{* *}$ & $\begin{array}{r}34 \cdot 8 \\
+6.3\end{array}$ & $\begin{array}{l}535 \cdot 9^{* *} \\
+80.5\end{array}$ & $\begin{array}{r}603 \cdot 5 \\
+131.5\end{array}$ & $98 \cdot 5^{*}$ & $1883 \cdot 0^{* *}$ \\
\hline+2 capsules & \pm 46.6 & $\pm 6 \cdot 3$ & \pm 89.5 & $\pm 131 \cdot 5$ & $\pm 25 \cdot 3$ & $\pm 266 \cdot 8$ \\
\hline Castrated & $250 \cdot 0$ & $23 \cdot 5^{* *}$ & $316 \cdot 2^{*}$ & $738 \cdot 0^{* *}$ & $25 \cdot 3^{*}$ & $628 \cdot 7^{*}$ \\
\hline+4 capsules & $\pm 41 \cdot 2$ & $\pm 13 \cdot 1$ & $\pm 159 \cdot 8$ & $\pm 172 \cdot 3$ & $\pm 7 \cdot 5$ & $\pm 300 \cdot 6$ \\
\hline
\end{tabular}

${ }^{*} P<0.001,{ }^{* *} P<0.05$ when compared with control values.

\section{Discussion}

Testosterone or $\mathrm{R} 1881$ could be used for the measurement of the androgen receptor but $\mathrm{R} 1881$ was the steroid of choice since, in contrast to testosterone (Hansson et al., 1975), no interference in the androgen receptor measurement resulted from the presence of the rete testis fluid. However, the use of this synthetic compound had to be validated since we, as well as others, have observed that $\mathrm{R} 1881$ is bound by the progesterone receptor with high affinity (Cowan, Cowan \& Grant, 1977). The results presented in Text-fig. 1 showed this validity; moreover we have not detected progesterone receptors in the epididymis under the conditions of this study. Since the androgen receptor concentration was higher in the caput epididymidis and the measurement more accurate, this segment only was studied in the ligation of the efferent ducts and castration experiments. The ligation of the efferent ducts had no effect on the androgen receptor concentration, suggesting an exclusive dependence of this concentration upon the androgens reaching the epididymis via the blood supply when compared with androgens reaching the epididymis with the intraluminal fluid.

Castration and testosterone treatment experiments were in agreement with previous work presented by other authors (Podesta, Calandra, Rivarola \& Blaquier, 1975; Blondeau et al., 1975; Calandra, Blaquier, Del Castillo \& Rivarola, 1975; Calandra, Purvis, Attramadal \& Hansson, 1977). The androgen receptor concentrations in both prostate and epididymis have been shown to be under the control of androgens. The highest concentration of androgen receptor observed with the highest dose of testosterone treatment ( 2 capsules) in the caput epididymidis and the ventral prostate was in good agreement with the other biological effects of testosterone (weight, protein and DNA content) observed in these organs, i.e. similar to normal controls for the epididymis, higher than the values observed in normal controls for the ventral prostate. At the highest dose of 4 capsules of testosterone, the hormonal effects on weight, DNA and protein content could not be increased, in agreement with previous reports (Coffey, Shimazaki \& Williams-Ashman, 1968). When the androgen receptor concentrations were measured in these conditions, a significant decrease was observed. At the present time we cannot offer a clear explanation for this observation.

Although clear variations of the androgen receptor concentration were noted in the various epididymal segments as well as in the caput epididymidis and ventral prostate after castration 
with or without testosterone treatment, the present data do not yet allow an explanation of the differential response of the different regions of the epididymis and of the other accessory glands to the administration of androgens. These variations may indeed reflect the relative abundance of different cell types (Hamilton, 1975) since androgen receptors are almost exclusively localized to the epithelial cells (Tindall et al., 1974; Hansson et al., 1975). Moreover the modulation of androgen action by the enzymic activities of these target tissues will also have to be considered in such an analysis.

We thank Dr I. Z. Beitins and Mr R. Baritaud for their assistance. This work was supported by the Délégation Générale à la Recherche Scientifique et Technique (Contrat BRD no. 7070814) and the World Health Organization.

\section{References}

Baulieu, E.-E., Atger, M., Best-Belpomme, M., Corvol, P., Courvalin, J.C., Mester, J., Milgrom, E., Robel, P., Rochefort, H. \& De Catalogne, D. (1975) Steroid hormone receptors. Vitams Horm. 33, 649-736.

Berndston, W.E., Desjardins, C. \& Ewing, L.L. (1974) Inhibition and maintenance of spermatogenesis in rats implanted with polydimethylsiloxane capsules containing various androgens. $J$. Endocr. 62, 125135.

Blaquier, J.A. (1971) Selective uptake and metabolism of androgens by rat epididymis. The presence of a cytoplasmic receptor. Biochem. Biophys. Res. Commun. 45, 1076-1082.

Blondeau, J.P., Corpechot, C., Le Goascogne, C., Baulieu, E.-E. \& Robel, P. (1975) Androgen receptors in the rat ventral prostate and their hormonal control. Vitams Horm. 33, 319-345.

Bonne, C. \& Raynaud, J.P. (1975) Methyltrienolone, a specific ligand for cellular androgen receptors. Steroids 26, 227-232.

Burton, K. (1956) A study of the conditions and mechanism of the diphenylamine reaction for the colorimetric estimation of deoxyribonucleic acid. Biochem. J. 62, 315-323.

Calandra, R.S., Blaquier, J.A., Del Castillo, J. \& Rivarola, M.A. (1975) Androgen dependency of the androgen receptor in rat epididymis. Biochem. Biophys. Res. Commun. 67, 97-102.

Calandra, R.S., Purvis, K., Attramadal, A. \& Hansson, V. (1977) Androgen receptors in rat epididymis do not disappear after castration. J. Steroid Biochem. 8, $1205-1206$.

Coffey, D.S., Sminazaki, J. \& Williams-Ashman, H.G. (1968) Polymerization of deoxyribonucleotides in relation to androgen-induced prostate growth. Archs Biochem. Biophys. 124, 184-198.

Cowan, R.A., Cowan, S.K. \& Grant, J.K. (1977) Binding of methyltrienolone ( $R$ 1881) to a progesterone receptor-like component of human prostatic cytosol. J. Endocr. 74, 281-289.
Gupta, G., Rajalakshmi, M. \& Prasad, M.R.N. (1974) Regional differences in androgen thresholds of the epididymis of castrated rat. Steroids 24, 575-584.

Hamilton, D.W. (1975) Structure and function of the epithelium lining the ductuli efferentes, ductus epididymidis, and ductus deferens in the rat. In Handbook of Physiology, Section 7: Endocrinology, vol. 5, pp. 259-301. Eds. D. W. Hamilton \& R. O. Greep. American Physiological Society, Washington, D.C.

Hansson, V., Ritzen, E.M., French, F.S. \& Nayfeh, S. (1975) Androgen transport and receptor mechanism in testis and epididymis. In Handbook of Physiology, Section 7: Endocrinology. vol. 5, pp, 173-201. Eds D. W. Hamilton \& R. O. Greep. American Physiological Society, Washington, D.C.

Lowry, O.H., Rosebrough, N.J., Farr, A.L. \& Randall, R.J. (1951) Protein measurement with the Folin phenol reagent. J. Biol. Chem. 193, 265-275.

Podesta, E.J., Calandra, R.S., Rivarola, M.A. \& Blaquier, J.A. (1975) The effect of castration and testosterone replacement on specific proteins and androgen levels of the rat epididymis. Endocrinology 95, 399-405.

Prasad, M.R.N., Rajalakshmi, M., Gupta, G. \& Karkun, T. (1973) Control of epididymal function. J. Reprod. Fert., Suppl. 18, 215-222.

Pujol, A., Bayard, F., Louvet, J.P. \& Boulard, Cl. (1976) Testosterone and dihydrotestosterone concentration in plasma, epididymal tissues and seminal fluid of adult rats. Endocrinology 98, 111-113.

Scatchard, G. (1953) The attractions of proteins for small molecules and ions. Ann. N.Y. Acad. Sci. 51, $660-672$.

Tindall, D.J., Hansson, V., Sar, M., Stumpf, W.E., French, F.S. \& Nayfeh, S.N. (1974) Further studies on the accumulation and binding of androgen in rat epididymis. Endocrinology 95, 1119-1128.

Received 16 September 1978 